\title{
Особенности пассивной синхронизации мод в волоконном высоколегированном иттербиевом лазере
}

\author{
$\underline{\text { А.М. Смирнов }}^{1,2, *}$, О.В. Бутов ${ }^{1}$ \\ ${ }^{I}$ Институт радиотехники и электроники им. В.А. Котельникова РАН \\ ${ }^{2}$ Московский государственный университет им. М.В. Ломоносова \\ *E-mail: alsmir1988@mail.ru
}

DOI: 10.31868/RFL2020.87-88

В данной работе нам впервые удалось создать цельно волоконный импульсный лазер на основе сильно легированного иттербиевого волокна, позволившего достичь частоты следования ультракоротких импульсов 456 МГц без применения дополнительных нелинейно-оптических элементов. Исследована динамика генерации высоколегированного иттербиевого волоконного лазера, собранного по классической схеме Фабри-Перо с двумя зеркалами при непрерывной прямой накачке сердцевины активного волокна на длине волны 976 нм. Показано формирование ультракоротких импульсов (УКИ) в результате пассивной синхронизации мод [1]. Пассивная синхронизация мод объяснена насыщением поглощения, при этом роль насыщающегося поглотителя, играл сам активный световод с высоким содержанием ионов иттербия. По своему принципу работа созданного нами лазера схожа с лазерами, работающими в режиме пассивной синхронизации мод с применением насыщающихся поглотителей $[2,3]$.

Для изготовления лазера использовался световод с высоким содержанием оксида иттербия, при относительно низкой концентрации крупных кластерных элементов , что позволило избежать высокого уровня «серых» потерь в активном волокне [4] (плазмохимический метод). Коэффициент поглощения на длине волны 976 нм составлял около 2,4 дБ/мм (Рис.1). Содержание иттербия в стекле, соответствующее измеренному коэффициенту поглощения, составляло 0,84 моль.\% $\mathrm{Yb}_{2} \mathrm{O}_{3}$ [5]. Разница в показателе преломления сердцевины и оболочки составляла 0,009, диаметр сердцевины - около 4 мкм. Лазер был собран по классической схеме Фабри-Перо с выходным $(0,9)$ и глухим $(0,999)$ зеркалом в виде волоконных брэгговских решеток (FBG) с максимумом отражения на длине волны 1067,7 нм. Для контроля двулучепреломлением в резонаторе использовался контроллер поляризации (РС).

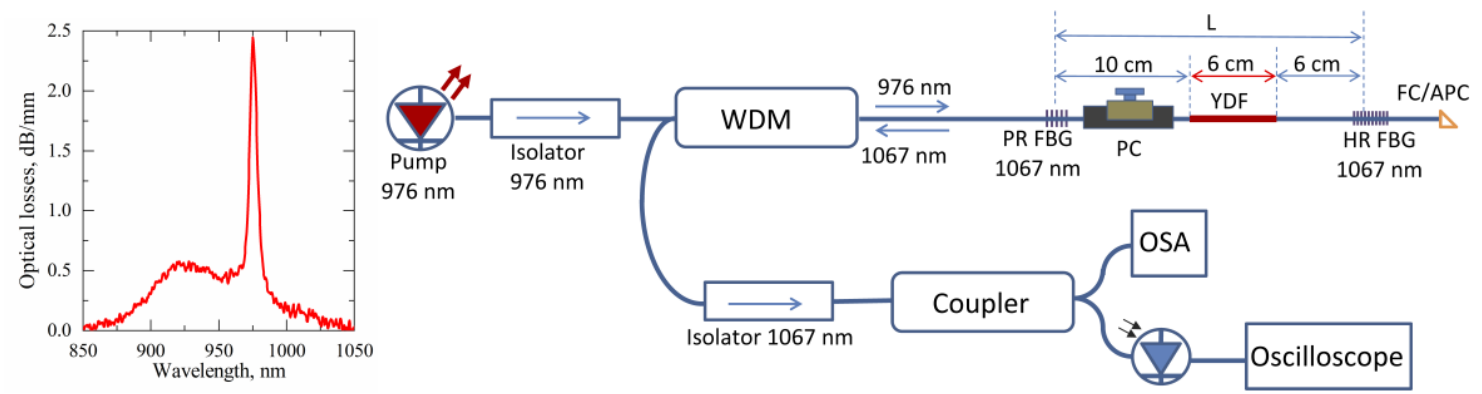

Рис. 1. Спектр поглощения иттербиевого активного волокна (слева). Схема экспериментальной установки иттербиевого лазера (справа). OSA - оптический анализатор спектра, WDM мультиплексор, PC - контроллер поляризации, L - длина резонатора. 
В зависимости от мощности накачки была продемонстрирована работа лазера в трёх разных режимах пассивной синхронизации мод. При малой мощности накачки ( $\approx 25-50$ мВт) достигнут стабильный режим пассивной синхронизации мод (CW ML), при котором амплитуда УКИ квазистабильна во времени (Рис.2a,b). Частота повторения УКИ для резонатора длиной 21,9 см составила 456 МГц. Период импульсов в цуге совпадает с временем обхода резонатора, что согласуется с общепринятой теорией пассивной синхронизации мод [6]: $\Delta \mathrm{t}=2 \mathrm{~nL} / \mathrm{c}$ (где $L$ - длина резонатора, $n$ - показатель преломления, $c$ скорость света). Наблюдаемая пассивная синхронизация мод в рассматриваемой схеме может быть объяснена нелинейным поглощением в самом активном волокне, который работает аналогично насыщающимся поглотителям. Эффект возникает на слабо прокаченном участке волоконного световода, в котором инверсия населённости, а соответственно, и уровень поглощения зависит от интенсивности вынужденного излучения в резонаторе.
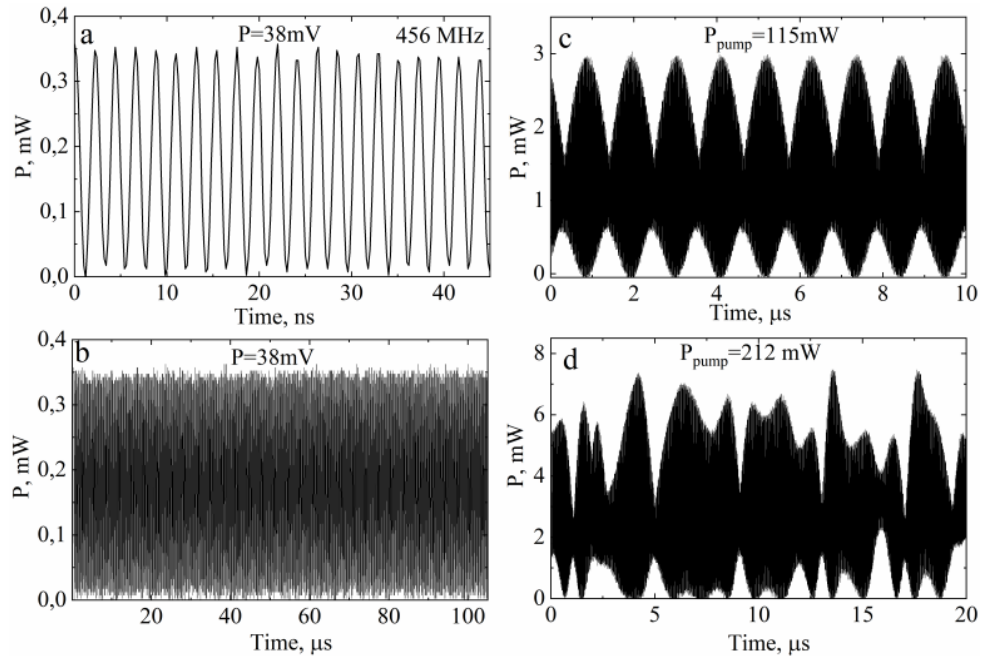

Рис. 2. Мощность генерации иттербиевого лазера в зависимости от времени при мощности накачки 38 мВт (стабильном режиме пассивной синхронизации мод) при 40 наносекундной (a) и 100 микросекундной развёртке (b), при мощности накачки 115 мВт (c) (режим биений) и при мощности накачки 212 мВт (d) (режим хаотических биений).

При увеличении мощности накачки ( $250-200$ мВт) возникали низкочастотные биения в виде модуляции амплитуды огибающей временной зависимости интенсивности генерации (Рис.2c). Обнаруженные биения были объяснены динамикой развития эллиптически поляризованной последовательности импульсов с вращающимися составляющими поляризации солитонов с фиксированной групповой скоростью (PRVS) [7]. При дальнейшем увеличении мощности накачки ( $200-310$ мВт) появлялись нерегулярные хаотические биения (TC ML) (Рис.2d).

\section{Литература}

[1] A.M. Smirnov, O.V.Butov, Optics Letters 44, 5065-5068 (2019)

[2] U. Keller, Nature 424, 831-838 (2003)

[3] A. J. DeMaria, D. A. Stetser, H. Heynau, Appl. Phys. Lett. 8, 174-176 (1966)

[4] K. Golant, Proceedings of XXI International Congress on Glass, L13 (2007)

[5] A.A. Rybaltovsky, O.V. Butov, et al, Tech. Phys. Lett. 42, 498-500 (2016)

[6] P.G. Kryukov, Quantum Electronics 31, 95-119 (2001)

[7] B.C. Collings, S.T. Cundiff, et al, JOSA B 17, 354-365 (2000) 